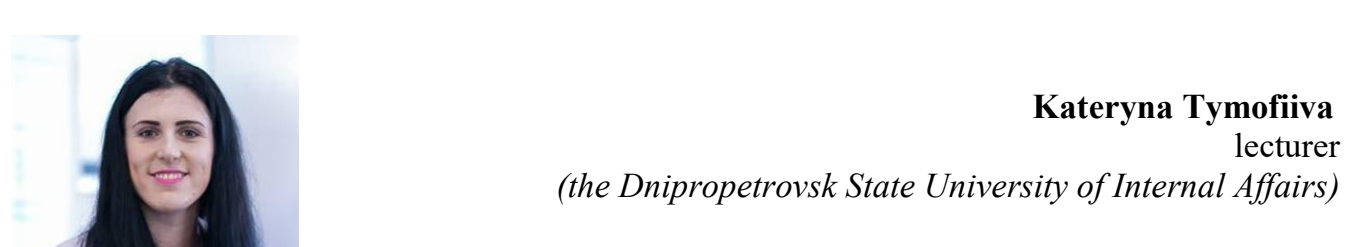

DOI: 10.31733 / 2078-3566-2018-2-232-236

\title{
MOTIVATION AND CAREER DEVELOPMENT AS KEY FACTORS IN THE UKRAINIAN POLICE
}

Тимофї̈ва К. МОТИВАЦІЯ ТА КАР'СРНИЙ РОЗВИТОК ЯК КЛЮЧОВІ ФАКТОРИ В ПОЛІЦІї УКРАЇНИ. У статті здійснено теоретичний аналіз питань мотивації та продуктивності працівників поліції України, а також розглянуто проблеми їх професійної мотивації з урахуванням специфіки цього виду державної служби в правоохоронній системі. Визначено, що ефективність службової діяльності працівників поліції певною мірою визначає іх трудова мотивація, а завданням сучаснихкерівників практичних підрозділів внутрішніх справ $\epsilon-$ забезпечити мотивуючі умови служби, здійснювати сприятливий мотиваційний вплив на підлеглих, забезпечити успішну професійнудіяльністькожногоправоохоронцяізлагодженуколективну роботу всього персоналу. Мотивований до службипрацівник сумлінно і результативно працює, самовиражаєтьсяу праці. Вибір лінії поведінки працівника визначають його трудові мотиви. Останні виражаються у внутрішньому спонуканнілюдини. Формування професіоналізму діяльності визначено як найважливішу характеристику працівників системи внутрішніх справ. Розглянуто теоретикометодологічні засади використання технологій мотивації стимулювання працівників системи ОВС та обгрунтовано напрями їх удосконалення.

Висвітлено питання пов'язані 3 професійною надійністю працівників поліції України: формування професійної надійності майбутніх поліцейських під час навчання, забезпечення професійної та функціональної надійності фахівців на робочому місці та прогнозування надійності працівників ОВС після довготривалого періоду несення служби. Проаналізовано та обгрунтовано ряд факторів, які безпосередньо впливають на розвиток професійної мотивації та робочої продуктивності працівників ОВС. Відношення на робочому місці, само-організація, стрес, стан здоров'я, заохочення та нагорода зі сторони керівництвавизначені домінуючими чинниками поліцейської продуктивної діяльності на робочому місці. У ході роботи визначено, що процес виявлення професійних мотивів i регулюваннятрудової мотивації правоохоронців $є$ досить складним і в той жечас необхідним для здійснення ефективного управління в ОВС.

Ключові слова:мотивачія, мотивачія прачівників поліції, ієрархія потреб, продуктивність, найвищі стандарти, фізична допомога, емоційна підтримка, методологічне керівництво.

Nowadays the issues of being police officer, protection of order and feeling of power are up to the day in our everyday life. Motivating police personnel can be complicated. Supervisors must work hard to ensure officers perform their duties efficiently and effectively. Many factors can negatively affect productivity and cause officers to become complacent, doing the bare minimum necessary. The difficult nature of crime fighting can cause officers to become cynical toward the population as a whole and develop an «us-versus-them» view [3]. A negative attitude in police work can lead to feelings of inconsequentiality toward law enforcement goals and either slow or stop internal motivation.

Officers who begin their careers with an attitude of «saving the world» can become jaded toward that goal after years of witnessing the worst in people. Constantly observing the aftermath of violent crimes, like robbery, rape, murder, and assault, eventually can take its toll on even the most dedicated officer. Administrators must look for ways to offset this constant bombardment of negativity while reinforcing the positive aspects of society and the benefits provided by quality law enforcement practices. This situation clarifies the urgency of this research.

The purposeof the article is to study the peculiarities of motivating police personnel and to scrutinizedthe ways of their professional self-development.

It is certainly true that this question was discussed by large number of different scien-

(C) Tymofiiva K., 2018 
tists and psychologists.But one of the most commonly cited theories of motivation is that of Abraham Maslow. According to his theory, people are motivated based on a hierarchy of needs [5]. At the bottom of this list are basic physiological essentials, such as food, water, and shelter. After obtaining these necessities, people look for safety, security, and a sense of belonging. Individuals then seek out praise and recognition for a job well-done that is related to a quest for improved self-esteem. This is followed by a desire for self-actualization or the potential to grow professionally[5].

A prominent feature of this theory is the need for praise and recognition under the selfesteem model. When properly used by management, praise can be an effective motivator of police personnel. Mark Twain once commented that he could live for two months on a compliment alone. Managers who strive to inspire personnel can adopt this adage and use it as an example of motivational philosophy.

Productivity and motivation are important in any organization. In police agencies, officers have a lot of freedom and discretion and often are unsupervised for many hours of the workday. The individual level of commitment and desire to serve the noble and ethical cause help guide officers' productivity and motivation on the job [2].

Many variables can influence on officers' levels of motivation, including supervisors' attitudes, job environment, and personal factors. Individuals experiencing family problems, health concerns, financial issues, or negative social experiences can exhibit significant declines in productivity and motivation. Job security often can help officers with personal problems as much as a stable personal life can assist them with a difficult work environment [4]. Administrators and direct supervisors seeking to improve work performance should understand this basic psychological process.

The community holds police to a high level of public trust while expecting them to prevent crime, maintain order, and provide an equal and unbiased application of law enforcement. To be an equal opportunity enforcement officer, the individual must be motivated to do the job and held accountable to the highest standards at all times. Fellow officers depend on each other for physical backup, emotional support, and technical guidance [2]. Lack of motivation can be contagious and cause problems for management if not recognized and treated early.

Agencies must have early warning systems in place to recognize symptoms and identify officers experiencing a decline in productivity or a lack of motivation [2]. Computer software programs can recognize possible early warning signs, such as decline in performance, suspicious sick leave patterns, unreasonable uses of force, and increased complaints. Such issues can indicate personal problems that result in a lack of motivation and productivity.

Several theories of motivation exist that supervisors could consider, including Maslow's Hierarchy of Needs, Herzberg's Motivation-Hygiene Theory. Administrators can learn many positive, as well as negative, points from these theories, but they all have one thing in common - the idea that supervisors must know their people [5]. To effectively manage motivation and productivity, leaders must possess the human skills needed to work with employees and have the empathy to understand their issues [5]. This idea also means that supervisors must work as a team with officers and build a cooperative effort for the common goal of the agency. By working closely with and understanding officers, effective leaders can identify problems earlier and create effective solutions to deal with those issues.

Physical fitness holds importance when discussing individual motivation and performance. Of course the first step of being productive in an organization is actually coming to work. Officers who participate in regular exercise programs less likely will develop healthrelated problems that keep them away from the job and negatively affect their work performance [4]. A police officer's job involves interacting with the public, entering and exiting police cars, walking up steps, apprehending suspects, and performing other physical activities dependent on a high level of physical fitness. Law enforcement leaders must take a hard look at agency physical training standards and long-term health programs to help ensure the highest levels of efficiency and effectiveness [4].

Much of a patrol officer's day is sedentary, often involving seemingly mundane duties, like operating radar from within cars or conducting routine patrol. But, such activities can be interrupted when officers receive calls to apprehend suspects or handle volatile situations. The dramatic increase in heart rate and adrenaline can strain vital organs and muscles not conditioned for this type of response [3].

Although often considered a responsibility of management, a certain level of motivation must come from within the individual. 
The profession of criminal justice is similar to others where the productivity of employees is vital to the bottom line. Whether a business involves farming, sales, construction, teaching, or public safety, evidence indicates that the motivation of the person doing the job is directly proportionate to the level of productivity in that industry [3]. In a criminal justice organization, individual health is important for improving attendance and productivity and related to the safety of the officer and the public. Most law enforcement personnel agree that appropriate physical fitness ensures safe and effective completion of essential job functions [3].

Resent research has shown that the key factors of police officers' motivation are depend on:

- stress

Law enforcement is broadly considered one of the most stressful occupations and often is associated with high rates of alcoholism, suicide, emotional health problems, and divorce [3]. All of these factors can negatively affect officers' motivation and productivity.

Organizations must strive to recognize and reduce stress associated with the profession to maximize job performance, motivation, and productivity [3]. Although the inherent dangers (e.g., apprehending suspects and facing assaults) of the law enforcement profession create a certain amount of stress, leaders can implement organizational changes that affect supervisory style, field training programs, critical incident counseling, shift work, and job assignments. These internal factors have been rated highly among police officers as major causes of stress. Some officers have reported that the job itself is not as stressful as a call to the supervisor's office [3].

Several consequences of police stress include cynicism, absenteeism, early retirement, emotional detachment from other aspects of daily life, reduced efficiency, increased complaints, and rises in health problems. In a recent survey, nearly 100 percent of respondents agreed that giving recognition can positively impact morale [3].

- praise and recognition

Money is an extrinsic motivator, while praise and recognition are intrinsic motivators. Effective leaders must stress the importance of such intrinsic motivators as achievement, recognition, fulfillment, responsibility, advancement, and growth [3].

- self-motivation

Although often considered a responsibility of management, a certain level of motivation must come from within the individual. In a 2003 study on the effects of self-motivation, the actions of police gang unit members in Gothenburg, Sweden were observed. The researcher identified several ways officers can reduce burnout and increase motivation to survive a long career in law enforcement. The intense stress of working constantly in tough, crime-ridden neighborhoods caused officers to desire transfers and redeploy to «nicer» areas as a way to avoid becoming too cynical [3].

Police officers also can seek different specialized jobs within the organization to help self-motivate and reduce individual stagnation. Large departments often have greater opportunities for internal transfers. Many officers in this study served for several years in the patrol division, then later applied for deployments as investigators, school resource officers, crime prevention officers, or specialized response-team members [2]. These jobs all require different training and varied core job responsibilities that can reinvigorate an officer's professional drive.

Because a substantial part of motivation remains with the officers themselves, the level and need for self-inspiration increases as officers rise in rank to supervisory roles [2]. An important part of a supervisor's function is to lead by example and, above all, have a positive attitude. Self-motivation is a prime ingredient in that formula. According to the U.S. Marine Corps officers' training statement, «Officers have to...self-motivate to keep themselves inspired and focused on the mission. This is the reason they don't sing cadences $\gg$ [2]. If leaders do not motivate themselves, who will do so? And, how can unmotivated leaders expect exceptional performance from subordinates?

Another way persons can increase their own motivation is by examining their strengths and what makes them truly happy and then looking at their weaknesses with a degree of selfexamination. For instance, someone could compile a journal with photographs of family members and special events that are inspiring and motivational. By reviewing and adding to the journal regularly, it can serve as a powerful motivator and a reminder for individual inspiration.

- attitude

Research data confirmed that officers' individual attitudes can influence their level of productivity and motivation. In one study officers who perceived traffic enforcement as a per- 
sonal priority engaged in more enforcement efforts and subsequently issued more citations [3]. They also were influenced by the ideal that management rewarded officers who issued more traffic tickets, and those who agreed with this perception followed suit.

- health and fitness

The health and physical fitness of officers also can affect their motivation. Many employers have seen increased absenteeism as a result of employees' health issues.Absent workers strain resources, reduce productivity, and increase costs. In police field units, manpower must be maintained at a minimum level, and illness or injury can cause serious cost overruns in overtime and sick-leave reimbursements. In law enforcement organizations, physical fitness is essential and can impede officer performance if not maintained.

To conclude, it should be added that administrators and managers in law enforcement agencies must remain cognizant of the many factors that can influence individual motivation and productivity of police officers. The nature of the job can result in officer burnout, followed by a decrease in the motivation to perform. Recruits starting out in law enforcement with a strong desire to change the world and who possess a great ethical desire to serve the noble cause easily can be swayed toward mediocrity by the contagiousness of other jaded officers. Although some officers who realize a decline in motivation can self-motivate by seeking out interdepartmental transfers or changes in duty assignments, many police agencies do not have such opportunities. In these smaller organizations, supervisors must work harder to discover other ways to improve an officer's performance.

The intrinsic factors of praise and recognition for a job well-done can help improve officers' attitudes and increase their desire for doing the job. As pointed out in Maslow's Hierarchy of Needs, the need for self-esteem is part of the makeup of all individuals. However, supervisors must rely on this sparingly and in coordination with other methods to avoid crossing the boundary of diminishing returns [3]. Too much emphasis on compliments and recognition easily can ruin officer's effectiveness; therefore, they must be distributed with reason and common sense.

Administrators also should recognize the stress associated with police work and strive to create a healthy organizational environment where officers are not subjected to harsh leadership. Police officers have sufficient worries while carrying out their responsibilities without the additional stress of managerial problems [3]. When officers perceive interacting with supervisors as causing more stress than dealing with criminals, a fair self-evaluation of management practices clearly is in order.

Management also must set the example for motivation. A positive attitude on the part of a supervisor can directly impact the motivation and productivity of subordinate officers [5]. This makes sense and follows the old saying of «lead by example», a useful adage for all leaders to follow.

Finally, the health and physical wellness of the officer is so important and universally recognized that completion of a physical fitness test is mandated in most recruit training programsEvidence reveals that the level of vitality and health of employees has an effect on the bottom line of achieving the goals of any organization, and the benefits of physical fitness can directly improve an individual's stress level [5]. Administrators who realize the importance of health and fitness can implement sound strategies and strive to improve the level of well-being within their organizations.

Enhancing the motivation and productivity of police officers is a difficult, yet achievable, objective. When administrators, supervisors, and officers are educated about the many ways this can be achieved, they consistently can work together for the common goal.

\section{References}

1. Emotional Survival for Law Enforcement // Kevin Gilmartin / A Guide for Officers and Their Families. Tucson, AZ: E-S Press, 2002.

2. Improving Workplace Productivity: It Isn't Just About Reducing Absence // Kathy Harte, Kathleen Mahieu, David Mallett, Julie Norville, and Sander Vander Werf / Benefits Quarterly (Third Quarter 2011). URL: http://www.aon.com/attachments/human capital consulting/Absence_Improving_Workforce_Productivity_5-7-13 pdf (accessed January 26, 2015).

3. Officer Attitudes and Management Influences on Police Work Productivity // Richard Johnson, American Journal of Criminal Justice 36, no. 4 (December 2011). P. 293-306. URL: http://link.springer.com/ article/10.1007\%2Fs12103-010-9090-2\# (accessed January 26, 2015).

4. Praise and Recognition: The Importance of Social Support in Law Enforcement // Tracey Gove, FBI Law Enforcement Bulletin, October 2005. P. 14-19. URL: http://leb.fbi.gov/2005-pdfs/leboctober-2005 (accessed January 26, 2015). 
5. Self-Motivation and Self-Improvement //Robin Dreeke, FBI Law Enforcement Bulletin, August 2008, under «Leadership Spotlight». URL: http://leb.fbi.gov/2008-pdfs/leb-august-2008 (accessed January 26, 2015).

Received to editorial office 12.06.2018

\section{Summary}

The article deals with the issues of motivation and career development of Ukrainian police officers. The factors influencing Ukrainian police productivity have been analyzed. The research is focused on the main points which influence on police motivation.

The results of the research show that enhancing the motivation and productivity of police officers is a difficult, yet achievable, objective.

Keywords: motivation, police officers' motivation, a hierarchy of needs, productivity, the highest standards, physical backup, emotional support, technical guidance.

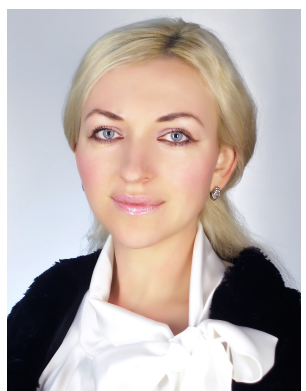

Oksana Ivchenko

trainer

(the Dnipropetrovsk State University of Internal Affairs)

DOI: 10.31733 / 2078-3566-2018-2-236-238

\section{ALGORITHM OF COMPLEX CONTROL OF TRAINING OF BASKETBALLIST AT THE PREVIOUS BASIS TRAINING STAGE}

Івченко О. АЛГОРИТМ КОМПЛЕКСНОГО КОНТРОЛЮ ПІДГОТОВКИ БАСКЕТБОЛІСТІВ НА ПОПЕРЕДНЬОМУ БАЗОВОМУ РІВНІ ПІДГОТОВКИ. ОДНИМ із напрямків підготовки $є$ якісний зміст та організація системи підготовки, яка базується на єдності організаційних, програмно-методичних основ, матеріально-технічних засобів процесу підготовки і реалізується комплексним використанням. Було виявлено, що в процесі підготовки баскетболістів на етапі попередньої базової підготовки приділяється незначна увага проблемі контролю різних сторін підготовленості й комплексній оцінці підготовленості. Запропонований нами алгоритм комплексного контролю підготовленості використовується для корекції навчально-тренувальної та змагальної діяльності і своєчасного виявлення недоліків та сильних сторін в певних компонентах підготовки. Облік динаміки показників підготовленості баскетболістів 13-14 років у річному циклі дозволить досить раціонально й точно формувати підготовку, вирішувати три групи завдань.

Контроль повинен здійснюватися в навчально-тренувальному процесі щорічно, 3 урахуванням організаційно-управлінських засобів і оптимальної організації науково-методичних особливостей підготовки юних баскетболістів 3 метою виявлення більш перспективних спортсменів й пошуку найефективніших засобів та методів оцінки підготовленості юних спортсменів на окремо визначеному етапі багаторічного вдосконалення.

Ключові слова: алгоритм, комплексний контроль, попередня базова підготовка, баскетбол.

Formulation of the problem. The problem of control preparation young basketballersis still one of the major in sport preparation children's and youth team, whose solutionwill prevent forcing educational trainingprocess of racing for victories in competitions, will contribute preservation of physical and mental health of young sportsmen, accordance the solution of tasks stage of long standingimproving content and intensity of training activity with account for individual and team differences $[1 ; 2 ; 3 ; 5]$.

Analysis of recent research and publications. In available literature of this problem $[4,5]$ data are provided, which display control of competition and training activities, status of varioussides of readiness of basketball players. Some authors suggest an algorithm of control competitive activity of highly qualified athletes: in sports games [1, 2, 4, 7]. Along with this, there is not enough information about the algorithm of complex control of the preparedness of athletes, who specialize in basketball, at the stage of preliminary basic training taking into account the lastachievements of sports science, and in particular, modern tendencies of competitive activity of young athletes during a one-year training cycle.

Presenting main material.The current state of the training process of basketball play-

(C) Ivchenko O., 2018 